\title{
T Cell Receptor Gamma and Delta Rearrangements in Hematologic Malignancies Relationship to Lymphoid Differentiation
}

\author{
Frank Griesinger, James M. Greenberg, * and John H. Kersey \\ Departments of Laboratory Medicine and Pathology and *Pediatrics, University of Minnesota, Minneapolis, Minnesota 55455
}

\begin{abstract}
We have studied recombinatorial events of the $T$ cell receptor $\delta$ and $\gamma$ chain genes in hematopoietic malignancies and related these to normal stages of lymphoid differentiation. $T$ cell receptor $\delta$ gene recombinatorial events were found in $91 \%$ of acute $T$ cell lymphoblastic leukemia, $68 \%$ of non- $T$, non-B lymphoid precursor acute lymphoblastic leukemia (ALL) and $80 \%$ of mixed lineage acute leukemias. Mature B-lineage leukemias and acute nonlymphocytic leukemias retained the $T$ cell receptor $\delta$ gene in the germline configuration. The incidence of $T$ cell receptor $\gamma$ and $\delta$ was particularly high in $\mathrm{CD10}^{+} \mathrm{CD}^{+}{ }^{+}$non-T, non-B lymphoid precursor ALL. In lymphoid precursor ALL, $T$ cell receptor $\delta$ was frequently rearranged while $T$ cell receptor $\gamma$ was in the germline configuration. This suggests that TCR $\delta$ rearrangements may precede TCR $\gamma$ rearrangements in lymphoid ontogeny. In T-ALL, only concordant $T$ cell receptor $\delta$ and $\gamma$ rearrangements were observed. Several distinct rearrangements were defined using a panel of restriction enzymes. Most of the rearrangements observed in T-ALL represented joining events of $J \delta 1$ to upstream regions. In contrast, the majority of rearrangements in lymphoid precursor ALL most likely represented D-D or V-D rearrangements, which have been found to be early recombinatorial events of the TCR $\delta$ locus. We next analyzed TCR $\delta$ rearrangements in five $\mathrm{CD3}^{+} \mathrm{TCR} \gamma / \delta^{+} \mathrm{ALL}$ and cell lines. One T-ALL, which demonstrated a different staining pattern with monoclonal antibodies against the products of the TCR $\gamma / \delta$ genes than the PEER cell line, rearranges $J \delta 1$ to a currently unidentified variable region.
\end{abstract}

\section{Introduction}

Leukemias are believed to represent clonal expansions of hematopoietic precursor cells arrested at varying stages of differentiation $(1,2)$. They provide an opportunity to study clonal populations of lymphoid cells at different stages of differentiation at the molecular level. These studies have provided important insight into the frequency, hierarchy, and diversity of rearrangements of members of the immunoglobulin supergene

Address reprint requests to Dr. J. H. Kersey, Department of Laboratory Medicine and Pathology, Box 86, UMHC, 420 Delaware Street, SE, Minneapolis, MN 55455.

Received for publication 19 December 1988 and in revised form 22 March 1989.

J. Clin. Invest.

(c) The American Society for Clinical Investigation, Inc. 0021-9738/89/08/0506/11 $\$ 2.00$

Volume 84, August 1989, 506-516 family. Recently, a fourth $\mathrm{T}$ cell receptor gene, $\operatorname{TCR}^{1} \delta$, has been identified (3-8). Its gene product is coexpressed as a heterodimer in conjunction with the TCR $\gamma$ chain on a subset of T lymphocytes with so far unknown function (3-9). Since the genomic repertoire of the TCR $\gamma$ chain gene appears to be very limited (10-14), the determination of the genomic diversity of the TCR $\delta$ chain gene is of great importance for a better understanding of antigens that are potentially detected by the $T$ cell receptor $\gamma / \delta$ chain. Due to its unique chromosomal localization within the TCR $\alpha$ locus, the TCR $\delta$ locus must be deleted when a functional $\mathrm{V} \alpha$-J $\alpha$ rearrangement occurs (3-6, 15-20). Therefore, the TCR $\delta$ locus may play a crucial role in early lymphoid ontogeny, and it may be helpful in elucidating the relationship of leukemic precursor cells to the T- and Blineages. Recently, a high incidence of TCR $\delta$ rearrangements and deletions of $80-90 \%$ has been reported $(21,22)$ in B cell precursor ALL. In order to come to a better understanding of these issues, the TCR $\delta$ and $\gamma$ gene rearrangements were studied in human lymphoid and myeloid malignancies and cell lines and questions of frequency and lineage association, hierarchy, and diversity of TCR $\delta$ recombinatorial events were addressed.

\section{Methods}

Fresh leukemic cells and cell lines. Patient samples were selected according to availability and sufficient material. Samples included patients enrolled in the Children's Cancer Study Group (CCSG) whose bone marrow samples were sent for immunophenotyping to the reference laboratory at the University of Minnesota and local pediatric and adult patients at the University of Minnesota and affiliated hospitals. Mononuclear cells were isolated from leukemic peripheral blood or bone marrow containing $>80 \%$ leukemic blasts as described previously (23-25). Leukemic cells and cell lines are listed in Table I based on immunophenotype and cytochemistry, as discussed later. The cell lines used in this study were established from patients with lymphoid, myeloid, and mixed lineage acute leukemias, as described elsewhere (23, 25). The cell lines Molt 3, Molt 4, HPB-mlt, HSB-2, Nalm 6, HPB-null, ML-2, ML-3 were generous gifts from Dr. J. Minowada. ML-2 and ML-3 (cases 65, 66) are well described cell lines from the same patient with acute myelogenous leukemia. The RS4;11 cell line (case 67) was established from a patient with ALL and displays the combination of lymphoid and monocytic characteristics in vitro as described in detail elsewhere (26). The DU.528.4 (27) cell line was a kindly provided by J. Kurtzberg and M. S. Hershfield, Duke University, Durham, NC. Two EBV-transformed cell lines were established

1. Abbreviations used in this paper: $\mathrm{AL}$, acute leukemia; $\mathrm{ALL}$, acute lymphoblastic leukemia; ANLL, acute nonlymphoblastic leukemia; C, constant region; CLL, chronic lymphocytic leukemia; D, diversity element; J, joining region; LCL, lymphoblastoid cell lines; LP-ALL, lymphoid precursor acute lymphoblastic leukemia; PE, phycoerythrin; SSPE, sodiumchloride, sodiumphosphate, EDTA; TE, Tris- $\mathrm{HCl}$, EDTA; TCR, T-cell antigen receptor; $V$, variable region. 
from B cells from a normal donor (FJO-LCL) and a patient post-bone marrow transplantation (TM-LCL), respectively.

MN-B3 (case 30) is a nonleukemic TCR $\gamma / \delta$ clone, established from the peripheral blood of a normal donor. Peripheral blood mononuclear cells were isolated as described and cultured in the presence of recombinant human IL-2 $200 \mathrm{U} / \mathrm{ml}$ (AMGen Biochemicals, Thousand Oaks, CA) for $10 \mathrm{~d}$. The cultured cells were sorted on a FACS IV (Becton, Dickinson \& Co., Mountain View, CA) for the CD3 ${ }^{+}$WT $31^{-}$ population and set up in bulk culture for additional $3 \mathrm{~d}$ in the presence of Identi-T $\delta$ TCS1 (T-Cell Sciences, Cambridge, MA) and IL-2 200 $\mathrm{U} / \mathrm{ml}$. The cells were subsequently subcloned by limiting dilution in the presence of IL-2 and irradiated EBV-transformed lymphoblastoid feeder cells.

Cytochemistry. The acute nonlymphoblastic leukemias and cell lines were positive for at least one of the following myeloid lineage associated cytochemical stains: myeloperoxidase, nonspecific esterase, chloroacetate esterase, leukocyte alkaline phosphatase. All fresh acute lymphoid leukemias, $\mathrm{T}$ and $\mathrm{B}$ cell lineage cell lines were negative for myeloid lineage associated cytochemical stains and had lymphoid morphology.

Immunophenotyping. The expression of surface membrane antigens on fresh and cultured leukemic and nonleukemic cells was determined on a cytofluorograph (Ortho Spectrum III; Ortho Diagnostic System, Raritan, NJ) or a FACS IV. Staining with unconjugated (for indirect immunofluorescence) and FITC- or phycoerythrin (PE)-conjugated (for direct immunofluorescence) MAb was carried out as described previously (23). Mouse control ascites and isotype matched directly conjugated $\operatorname{IgG}_{1,2}$ a , and (Becton, Dickinson \& Co.; Coulter Immunology, Hialeah, FL) served as negative control for indirect and direct fluorescence staining, respectively. The following panel of unconjugated and conjugated MAb was used (cluster designation, CD, where available, is given in brackets): OKT6 (CD1); 13B3 (CD2); OKT3, Leu4-PE (CD3); Leu3, Leu3-FITC (CD4); T101 (CD5); 3A-1. G3.7, Leu9-FITC (CD7); OKT8, Leu2-FITC (CD8); BA-2 (CD9); BA-3, J5-PE (CD10); MCS-2 (CD13); MY3 (CD14); B43, Leu12FTIC, Leu 12-PE, B4 (CD19); BA-1 (CD24); MY9, MY9-PE (CD33); MY10, HPCA-1 (CD34); T10 (CD38); MY8 and Leu 19-PE. The Leu series as well as HPCA-1 were purchased from Becton, Dickinson \& Co., the OKT series from Ortho, J 5 and the MY series from Coulter Immunology, the remaining MAb were kindly provided by $\mathrm{T}$. $\mathrm{W}$. LeBien and D. A. Vallera. The following MAb were used against the TCR $\gamma / \delta$ gene products: Identi-T $\delta$ TCS1 (T-Cell Sciences), which detects a subpopulation of TCR $\delta$ cells; 5A6.E9 (TCR $\delta 1$ ) kindly provided by M. Brenner, Dana Farber Cancer Institute, Boston, MA, which most likely detects a TCR $\delta$ chain framework structure (28); antiTCR gamma/delta (11 F 2), kindly provided by J. Borst, The Netherlands Cancer Institute, Amsterdam, Netherlands, with specificity for TCR $\gamma / \delta$ cells (29); anti-Ti $\gamma$ A, kindly provided by Th. Hercend, Pasteur Institute, Paris, France, which specifically detects an epitope on the gene product of a $\mathrm{V}_{\gamma} 9-\mathrm{J} \gamma 1.2$ rearrangement (30).

$T$-ALL and T-lineage cell lines. Based on the presence $(\geq 20 \%$ of cells positive) of CD1, CD2, CD3, CD4, CD5, CD7 and/or CD8 and the absence $(<20 \%$ positive) of more than one B-lineage associated antigens (CD10, CD19, CD24) and myeloid markers, 33 ALL and cell lines were defined as belonging to the T-lineage. These were further assigned to four different groups as shown in Table I: I: Early thymocyte $\left(\mathrm{CD} 1^{ \pm} \mathrm{CD} 2^{ \pm} \mathrm{CD}^{-} \mathrm{CD}^{-} \mathrm{CD}^{ \pm} \mathrm{CD}^{+} \mathrm{CD} 8^{-} \mathrm{CD} 10^{ \pm} \mathrm{HLA} \mathrm{DR}^{ \pm}\right.$ $\mathrm{TdT}^{ \pm}$): cases $1-12$, II: Common thymocyte $\left(\mathrm{CD}^{ \pm}{ }^{ \pm} \mathrm{CD}^{+}{ }^{+} \mathrm{CD}^{-}{ }^{-} \mathrm{CD} 4\right.$ and/or $\mathrm{CD}^{+} \mathrm{CD}^{+} \mathrm{CD}^{+} \mathrm{CD}^{-} 0^{-} \mathrm{HLA} \mathrm{DR}^{-}$): cases 13-23, III: Mature $\mathrm{TCR} \alpha / \beta$ expressing lymphocyte $\left(\mathrm{CD}^{-} \mathrm{CD}^{+} \mathrm{CD}^{+} \mathrm{CD} 4\right.$ or $\mathrm{CD} 8^{+}$ $\mathrm{CD}^{+}{ }^{\mathrm{CD}} 7^{+} \mathrm{CD} 10^{-} \mathrm{HLA} \mathrm{DR}^{-} \mathrm{WT} 31^{+} \delta$-TCS- $1^{-}, \mathrm{T} \gamma / \delta^{-}, \mathrm{TCR} \delta$ $\left.1^{-}, \operatorname{Ti} \gamma A^{-}\right)$: cases 24-28, IV: Mature TCR $\gamma / \delta$ expressing lymphocyte $\left(\mathrm{CD}^{-}{ }^{-\mathrm{CD}} 2^{+} \mathrm{CD}_{3}{ }^{+} \mathrm{CD}^{-}{ }^{-} \mathrm{CD}{ }^{+} \mathrm{CD}^{+}{ }^{+} \mathrm{CD} 8^{-} \mathrm{CD} 10^{-} \mathrm{HLA}\right.$ DR ${ }^{-} \mathrm{WT} 31^{-} \delta \mathrm{TCS}-1^{ \pm} \mathrm{T} \gamma / \delta^{+}$or TCR $\delta 1^{+}$, Ti $\gamma \mathrm{A}^{ \pm}$): cases 29-33 (31).

The PEER cell line, which has a functional $\mathrm{V}_{\gamma} 8-\mathrm{J} \gamma 2.3$ rearrangement (32) and the nonleukemic T $\gamma / \delta$ clone MN-B3 (case 30) were negative with $\mathrm{Ti} \gamma \mathrm{A}(30)$, which binds an epitope on the gene product of a $\mathrm{V} \gamma$ 9-J $\gamma 1.2$ join (12), but stained positive with all the anti-TCR $\delta$ monoclonal antibodies used in this study $(\delta \mathrm{TCS}-1, \mathrm{~T} \gamma / \delta(29)$, and TCR $\delta 1$ ). Cases 31 and 32 had a CD $3^{+} \mathrm{WT} 31^{-}$phenotype and expressed the TCR $\gamma$ chain demonstrated by immunoprecipitation as previously reported (14). No material was available for further immunophenotypic studies using the antibodies described above. The leukemic blasts of case 33 expressed CD3 and were T $\gamma / \delta^{+}$, TCR $\delta 1^{+}$, WT $31^{-}$, $\delta \mathrm{TCS}-1^{-}, \mathrm{Ti} \gamma \mathrm{A}^{-}$, which is consistent with the presence of a $\mathrm{T} \gamma / \delta$ receptor on the cell surface $(28,29,32,33)$. Notably, a different staining pattern from PEER and MN-B3 was observed in this leukemia. Additionally, the coexpression of CD19 on the cell surface or the leukemic blasts was demonstrated by staining with the monoclonal anti-CD19 antibodies B4, B43, and Leu 12.

Mature B-lymphocytic leukemias, lymphomas, and cell lines. 15 leukemias and cell lines were called mature B-lineage malignancies based on the presence of monotypic immunoglobulin heavy and/or light chains on the cell surface and the absence of $T$ or myeloid lineage associated antigens and cytochemical stains (Table I). These included six B-CLL (cases 34-39), two B-cell lymphomas (case 40, 41), one Burkitt's lymphoma (case 42), two follicular lymphomas (cases 43, 44), two EBV transformed lymphoblastoid cell lines (cases 45,46 ) and two Burkitt's cell lines Raji and Daudi (cases 47, 48).

Fresh ANLL and myeloid cell lines. 16 ANLL and myeloid cell lines were defined based on the positivity of myeloid lineage cytochemical stains. Phenotypic characteristics of cases 49-64 are shown in Table I. All expressed the panmyelomonocytic antigen CD13 (MCS-2) and at least one of the following antigens associated with the myeloid lineage: CD15, MY 8, or CD33. Cases 49-53 were CD7 ${ }^{+}$ANLL, cases 49 and 50 were $\mathrm{TdT}^{+}$. Only the morphology and the cytochemical stains of cases 61-64 were available, they were all myeloperoxidase positive ANLL M4 according to the FAB classification (35). The KG-1 cell line expressed $\mathrm{CD} 7$, which differs from the published phenotype (36).

Mixed lineage $A L$ and leukemic cell lines. Mixed lineage acute leukemias (mixed lineage $\mathrm{AL}$ ) were defined by the coexpression of antigens or cytochemical stains associated with different lineages on the same leukemic cell. The phenotypic characteristics of five mixed lineage $\mathrm{AL}$ and leukemic cell lines are shown in Table I. Coexpression of antigens associated with different lineages was demonstrated by dual color phenotyping as outlined in Methods. Case 68 showed a complex phenotype with B lineage associated antigens CD9, CD10, CD19, CD24 and the $T$ lineage associated antigen CD7. Coexpression of CD7 with CD10 and CD19 was directly demonstrated by two-color flow cytometry on $45 \%$ of the leukemic blasts. The leukemic blasts of case 69 had a lymphoid morphology, $40 \%$ were $\mathrm{TdT}^{+}$and negative for all cytochemical stains associated with the myeloid lineage. The leukemic blasts displayed a phenotype consistent with an early thymocyte $\left(\mathrm{CD}^{+} \mathrm{CD}^{+}\right)$, however they coexpressed the panmyelomonocytic antigen $\mathrm{CD} 13$ and $\mathrm{CD} 33$, which is found on granulocyte-monocyte precursor cells (CFU-GM) (reviewed in 37). Coexpression of CD7 and CD33 was directly demonstrated by two color flow cytometry on $45 \%$ of the leukemic blasts.

Other lymphoid precursor ALL and leukemic cell lines. Based on the absence of $T$ and myeloid lineage associated antigens and the absence of mature B lymphocyte differentiation antigens, a group of 31 ALL and leukemic cell lines were defined as lymphoid precursor ALL (cases 70-100, Table I). These cases generally expressed the CD19 antigen.

DNA extraction. High molecular weight DNA was extracted from fresh and cultured leukemic cells by proteinase $K$ digestion in TE, $\mathrm{NaCl} 0.1 \mathrm{M}, 1 \%$ SDS, subsequently two phenol/chloroform/isoamyl alcohol (25:24:1) and two chloroform/isoamyl alcohol (24:1) extractions. Finally the DNA was precipitated with absolute ethanol, dried, and resuspended in TE pH 7.4, as previously described (23).

Detection of gene rearrangements. Southern blot analysis was performed according to standard methods (23). Briefly, high molecular weight DNA, digested to completion with Eco RI, Bam HI, Xba I, and Hind III (Bethesda Research Laboratories Life Technology, Inc., Gaithersburg, MD) was size fractionated on 0.6 or $0.8 \%$ agarose gel 


\begin{tabular}{|c|c|c|c|c|c|c|c|c|c|c|c|c|c|c|c|c|c|c|}
\hline T-ALL: & CDI & $\mathrm{CD} 2$ & CD3 & CD4 & CD5 & $\mathrm{CD} 7$ & CD8 & CD10 & CD19 & CD24 & & & & & & TCR $\delta$ & $\begin{array}{c}\text { TCR } \delta \text { Rearr. } \\
\text { Eco RI/ } \\
\text { Bam HI }\end{array}$ & $\mathrm{TCR} \gamma$ \\
\hline \multicolumn{19}{|l|}{ I: Early thymocyte } \\
\hline 1 RPMI 8402 & - & + & - & - & + & + & - & - & - & - & & & & & & R/D & $23 / 13$ & $\mathbf{R} / \mathbf{R}$ \\
\hline 2 DU .528.4 & - & + & - & - & + & + & - & - & - & - & & & & & & R/D & $16 / 8$ & $\mathbf{R} / \mathbf{R}$ \\
\hline 3 & - & - & - & - & - & + & - & - & - & - & & & & & & G & & G/G \\
\hline 4 & - & - & - & - & - & + & - & - & - & - & & & & & & $R / G$ & $3.5 /<23$ & $\mathbf{R} / \mathbf{R}$ \\
\hline 5 & - & - & - & - & + & + & - & - & - & - & & & & & & $\mathbf{R} / \mathbf{R}$ & $\begin{array}{l}2.0 / 9.0^{*} \\
1.9 / 15.5^{*}\end{array}$ & $\mathbf{R} / \mathbf{R}$ \\
\hline 6 & - & + & - & - & - & + & - & - & - & - & & & & & & G & & $G / G$ \\
\hline 7 & - & + & - & - & + & + & - & + & - & ND & & & & & & G & & G/G \\
\hline 8 & + & + & - & - & + & + & - & - & - & - & & & & & & $\mathbf{R} / \mathbf{R}$ & $\begin{array}{l}4.0 / 11.5 \\
2.9 / 10.0\end{array}$ & $R / G$ \\
\hline 9 & - & - & - & - & - & + & - & - & - & - & & & & & & R/D & $4.0 / 11.5$ & $\mathbf{R} / \mathbf{R}$ \\
\hline 10 & - & - & - & - & + & + & - & - & - & - & & & & & & $\mathbf{R} / \mathbf{R}$ & & $\mathbf{R} / \mathbf{R}$ \\
\hline 11 & - & + & - & - & + & + & - & - & - & - & & & & & & $\mathrm{D} / \mathrm{D}, \mathrm{V}: \mathrm{G}$ & & $R / R$ \\
\hline 12 & ND & + & - & - & + & + & - & - & - & - & & & & & & $\mathrm{R} / \mathrm{D}$ & $1.0 / 12.0$ & $\mathbf{R} / \mathbf{R}$ \\
\hline \multicolumn{19}{|l|}{$\begin{array}{l}\text { II: Common } \\
\text { thymocyte }\end{array}$} \\
\hline 13 HSB-2 & - & - & - & \pm & + & - & - & - & - & - & & & & & & $\mathrm{D} / \mathrm{D}, \mathrm{V}: \mathrm{G}$ & & $\mathbf{R} / \mathbf{R}$ \\
\hline 14 Molt 4 & + & \pm & - & + & + & + & \pm & - & - & - & & & & & & D/D & & $\mathbf{R} / \mathbf{R}$ \\
\hline 15 Molt 3 & - & + & - & \pm & + & + & \pm & - & - & - & & & & & & $\mathrm{D} / \mathrm{D}$ & & $\mathbf{R} / \mathbf{R}$ \\
\hline 16 CEM & - & - & - & + & + & + & - & - & - & - & & & & & & $\mathrm{D} / \mathrm{D}, \mathrm{V}: \mathrm{G}$ & & $\mathbf{R} / \mathbf{R}$ \\
\hline 17 & + & + & - & + & + & + & + & - & - & - & & & & & & $\mathrm{R} / \mathrm{G}$ & $4.6 / 15$ & $R / R$ \\
\hline 18 & + & + & - & + & + & + & + & \pm & - & - & & & & & & $\mathbf{R} / \mathbf{R}$ & $\begin{array}{l}7.0 / 17.0 \\
7.0 / 9.6\end{array}$ & $R / G$ \\
\hline 19 & - & + & - & + & + & + & + & - & - & - & & & & & & $\mathrm{D} / \mathrm{D}$ & & $R / G$ \\
\hline 20 & \pm & + & - & - & - & + & + & - & - & - & & & & & & R/D & $7.0 / 17.0$ & $R / G$ \\
\hline 21 & + & - & - & + & - & + & - & - & - & - & & & & & & $\mathbf{R} / \mathbf{R}$ & $\begin{array}{l}3.5 />23 \\
2.9 / 10.0\end{array}$ & $\mathbf{R} /$ \\
\hline 22 & - & + & - & - & + & + & + & + & - & - & & & & & & $\mathbf{R} / \mathbf{R}$ & $\begin{array}{l}3.5 />23 \\
1.0 / 12\end{array}$ & $\mathbf{R} /$ \\
\hline 23 & + & + & - & - & + & + & + & - & - & - & & & & & & R/D & $2.9 / 10.0$ & $\mathbf{R} / \mathbf{R}$ \\
\hline $\begin{array}{l}\text { III: Mature TCR } \alpha / \beta \\
\text { lymphocyte }\end{array}$ & & & & & & & & & & & WT31 & & & & & & & \\
\hline 24 HPB-mlt & + & + & + & + & + & + & + & - & - & - & + & & & & & $\mathrm{D} / \mathrm{D}$ & & R/D \\
\hline 25 JURKAT & \pm & + & + & - & + & + & - & - & - & - & + & & & & & $\mathrm{D} / \mathrm{D}$ & & $R / R$ \\
\hline 26 & - & + & + & - & + & + & - & - & - & - & + & & & & & D/D, V:G & & $\mathrm{R} /$ \\
\hline 27 & - & + & + & + & + & + & + & - & - & - & + & & & & & $\mathrm{D} / \mathrm{D}$ & & $R / R$ \\
\hline 28 & - & + & + & - & + & + & - & - & - & - & + & & & & & R/D & $1.0 / 12$ & $R / R$ \\
\hline $\begin{array}{l}\text { IV: Mature TCR } \gamma / \delta \\
\text { lymphocyte }\end{array}$ & & & & & & & & & & & WT31 & TCR $\delta 1$ & $\delta$ TCS-1 & $\mathrm{T} \gamma / \delta$ & Tir A & & & \\
\hline 29 PEER & - & - & + & - & + & + & - & - & - & - & - & + & + & + & - & R/D & $3.5 />23$ & $\mathbf{R} / \mathbf{R}$ \\
\hline $30 \mathrm{MN}-\mathrm{B} 3$ & ND & ND & + & - & + & + & - & - & - & - & - & ND & + & ND & - & $\mathbf{R} / \mathbf{R}$ & $\begin{array}{l}3.5 />23 \\
2.9 / 10.0\end{array}$ & $R / R$ \\
\hline 31 & - & \pm & + & - & - & + & - & - & - & - & - & ND & ND & ND & ND & $R / G$ & $3.5 />23$ & $R / R$ \\
\hline 32 & \pm & - & + & \pm & - & + & - & - & - & - & - & ND & ND & ND & ND & $\mathrm{R} / \mathrm{G}$ & $3.5 />23$ & $R / G$ \\
\hline 33 & - & + & + & - & + & + & - & - & + & - & - & + & - & + & - & $\mathbf{R} / \mathbf{R}$ & $\begin{array}{l}6.0 / 17.0 \\
4.0 / 11.5\end{array}$ & $\mathrm{R} / \mathrm{R}$ \\
\hline
\end{tabular}

Mature B-lineage $\quad \mathrm{CD} 2 \mathrm{CD} 5 \mathrm{CD} 9 \mathrm{CD} 10 \mathrm{CD} 19 \mathrm{CD} 20 \mathrm{CD} 24 \quad$ HLADR $\operatorname{lgH}_{\mathrm{sm}} \mathrm{IgL}_{\mathrm{sm}}$ malignancies:

\begin{tabular}{|c|c|c|c|c|c|c|c|c|c|c|c|c|}
\hline 34 & - & ND & - & - & + & + & + & + & $\mathrm{IgD}$ & $\lambda$ & G & G/G \\
\hline 35 & \pm & + & - & - & + & + & + & + & ND & $\kappa$ & G & $\mathrm{G} / \mathrm{G}$ \\
\hline 36 & \pm & + & - & - & + & + & + & + & ND & $\lambda$ & G & G/G \\
\hline 37 & - & + & \pm & - & + & + & + & + & IgM & $\lambda$ & G & G/G \\
\hline 38 & - & + & - & - & ND & + & + & + & IgM & $\kappa$ & G & G/G \\
\hline 39 & - & - & - & - & + & ND & + & + & IgM & $\kappa$ & G & G/G \\
\hline 40 & \pm & + & - & - & + & + & + & + & ND & $\kappa$ & G & G/G \\
\hline 41 & - & + & + & - & + & + & + & + & ND & $\kappa$ & $\mathbf{G}$ & G/G \\
\hline 42 & - & ND & - & - & \pm & + & + & ND & IgM & $\lambda$ & G & G/G \\
\hline 43 & - & - & \pm & + & + & + & + & + & IgM & $\lambda$ & G & G/G \\
\hline 44 & - & - & + & + & ND & + & + & + & IgM & $\lambda$ & G & $\mathrm{G} / \mathrm{G}$ \\
\hline 45 TM-LCL & - & - & - & - & + & + & + & + & IgM & $\kappa$ & G & $\mathbf{G} / \mathbf{G}$ \\
\hline 46 FJO-LCL & - & - & - & - & + & + & - & + & IgM & $\lambda$ & G & G/G \\
\hline 47 DAUDI & - & - & - & + & + & + & ND & + & IgM & $\kappa$ & G & G/G \\
\hline 48 RAJI & - & - & - & + & + & + & ND & + & IgD & - & G & G/G \\
\hline
\end{tabular}


Table I. (Continued)

ANLL and myeloid CD2 CD7 CD9 CD10 CD19 CD24 HLADR CD13 CD14 CD15 CD33 My8 cell lines:

\begin{tabular}{|c|c|c|c|c|c|c|c|c|c|c|c|c|c|c|}
\hline 49 & - & + & + & - & - & - & + & + & - & - & + & \pm & $\mathbf{G}$ & $\mathbf{G} / \mathbf{G}$ \\
\hline 50 & - & + & - & - & - & - & + & + & - & + & + & - & $\mathbf{G}$ & $\mathbf{G} / \mathbf{G}$ \\
\hline 51 & \pm & \pm & + & - & ND & - & + & + & - & \pm & - & - & G & G/G \\
\hline 52 & - & + & - & - & ND & - & + & + & \pm & + & - & - & G & $\mathbf{G} / \mathbf{G}$ \\
\hline 53 & - & + & - & - & - & - & + & \pm & - & + & + & - & G & $\mathbf{G} / \mathbf{G}$ \\
\hline 54 & \pm & - & + & - & - & - & + & + & \pm & \pm & + & + & G & $\mathbf{G} / \mathbf{G}$ \\
\hline 55 HL-60 & - & ND & + & - & ND & - & - & + & - & + & + & ND & G & G/G \\
\hline 56 K562 & ND & ND & - & - & ND & ND & + & - & - & + & - & ND & G & $\mathbf{G} / \mathbf{G}$ \\
\hline 57 KG-1 & - & + & - & - & - & - & + & + & ND & ND & + & ND & G & $\mathbf{G} / \mathbf{G}$ \\
\hline $58 \mathrm{KG}-1 \mathrm{a}$ & - & + & - & - & - & - & - & + & ND & ND & - & ND & G & G/G \\
\hline 59 & - & - & + & - & - & - & + & + & - & + & + & + & $\mathbf{G}$ & G/G \\
\hline 60 & \pm & - & - & - & - & - & + & + & + & + & + & + & $\mathbf{G}$ & G/G \\
\hline 61 & & & & & & & & & & & & & $\mathbf{G}$ & G/G \\
\hline 62 & & & & & & & & & & & & & $\mathbf{G}$ & G/G \\
\hline 63 & & & & & & & & & & & & & $\mathbf{G}$ & G/G \\
\hline 64 & & & & & & & & & & & & & $\mathbf{G}$ & $\mathbf{G} / \mathbf{G}$ \\
\hline
\end{tabular}

Mixed lineage acute

leukemias and cell

lines: $\quad \mathrm{CD} 2 \mathrm{CD} 3 \mathrm{CD} 4 \mathrm{CD} 5 \mathrm{CD} 7 \mathrm{CD} 8 \mathrm{CD} 9 \quad \mathrm{CD} 10$ CD19 CD24 HLADR CD13 CD33

\begin{tabular}{|c|c|c|c|c|c|c|c|c|c|c|c|c|c|c|c|c|}
\hline \multirow[t]{2}{*}{$65 \mathrm{ML}-2$} & - & - & + & - & + & - & ND & - & - & - & + & + & + & $\mathbf{R} / \mathbf{R}$ & $7.0 / 17.0$ & $\mathbf{R} / \mathbf{R}$ \\
\hline & & & & & & & & & & & & & & & $7.0 / 9.6$ & \\
\hline \multirow[t]{2}{*}{$66 \mathrm{ML}-3$} & - & - & \pm & - & + & - & ND & - & - & - & + & + & + & $\mathbf{R} / \mathbf{R}$ & $7.0 / 17.0$ & $\mathbf{R} / \mathbf{R}$ \\
\hline & & & & & & & & & & & & & & & $7.0 / 9.6$ & \\
\hline 67 RS 4;11 & - & - & - & - & - & - & + & - & + & + & + & - & ND & $\mathrm{D} / \mathrm{D}, \mathrm{V}: \mathrm{G}$ & & $G / G$ \\
\hline 68 & - & - & - & - & + & - & \pm & + & + & \pm & + & - & - & R/D & $7.0 / 17.0$ & $\mathbf{R} / \mathbf{R}$ \\
\hline 69 & + & - & - & - & + & - & + & - & - & - & + & + & + & $\mathbf{G}$ & & G/G \\
\hline
\end{tabular}

Lymphoid precursor CD2 CD5 CD7 CD9 CD10 CD19 CD24 HLADR

ALL:

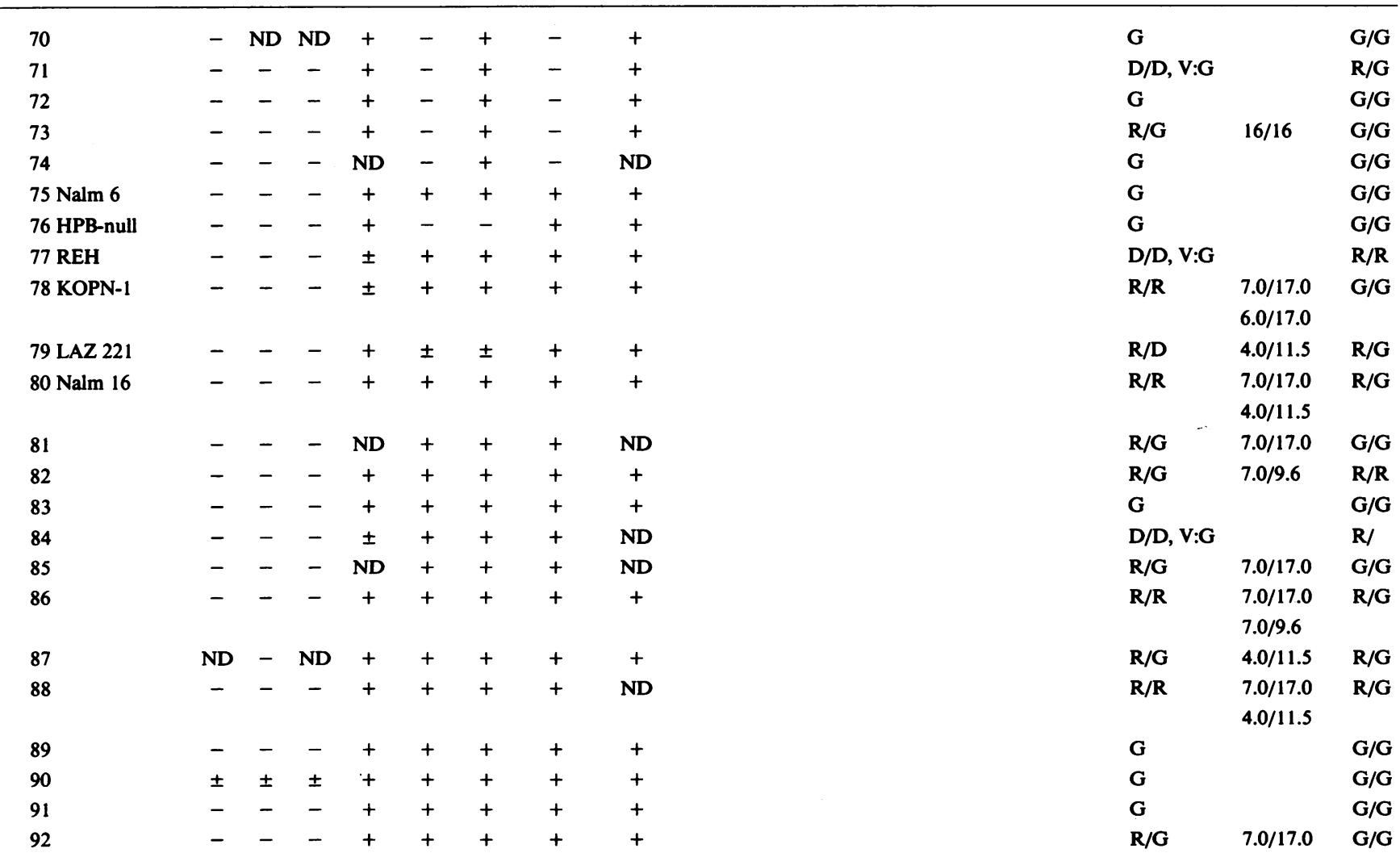


Lymphoid precursor CD2 CD5 CD7 CD9 CD10 CD19 CD24 HLADR ALL:

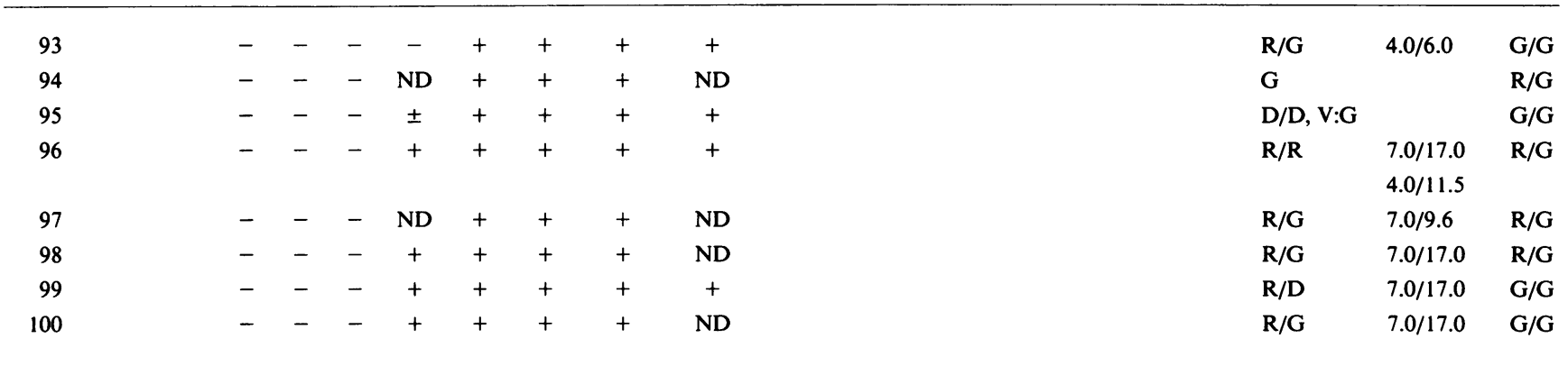

and transferred on a Nylon membrane (Nytran; Schleicher and Schuell, Inc., Keene, NH) in $10 \times$ SSPE. After washing and baking, the membrane was prehybridized for 2-4 h and hybridized for $20 \mathrm{~h}$ at $42^{\circ} \mathrm{C}$ according to the manufacturer's instructions. Probes were labeled with $\left[{ }^{32} \mathrm{P}\right] \alpha \mathrm{dCTP}$ to high specific activity by the random primer method (38), for filter hybridization. The membranes were washed twice for $15 \mathrm{~min}$ with $6 \times \mathrm{SSPE}, 0.1 \%$ SDS at room temperature, twice for $15 \mathrm{~min}$ with $1 \times \mathrm{SSPE}, 0.5 \% \mathrm{SDS}$ at $37^{\circ} \mathrm{C}$ and finally with $0.1 \times$ SSPE, $1 \%$ SDS at $60-65^{\circ} \mathrm{C}$ for $30 \mathrm{~min}$. Autoradiography was carried out on Kodak XR film with two intensifying screens for 14-72 $h$ at $-70^{\circ} \mathrm{C}$.

Rearrangements of the TCR $\delta$ gene were detected using three different probes: a genomic $\mathrm{J} \delta 1$ probe, $\mathrm{J} \delta \mathrm{S} 16$, kindly provided by $\mathrm{T}$. $\mathrm{H}$. Rabbitts, MRC, Cambridge, UK (16), a genomic TCR $\delta$ constant region probe p $\delta 7$ (Greenberg, J. M., C. W. Wilkowski, and J. H. Kersey, unpublished results) and the cDNA probe 0/240-38 (5), kindly provided by $M$. S. Krangel, Dana Farber Institute, Boston, MA. O/240-38 detects $V \delta 1$ (according to the nomenclature of references 19,39 , see note added in proof), $\mathrm{J} \delta 1$ and part of the constant region of the TCR $\delta$ gene (Fig. 1).

Rearrangements of the TCR $\gamma$ gene were detected in Bam HI and Eco RI digests with a 1.6-kb Eco RI/Eco RI cDNA probe pT $\gamma 1$ (40) kindly provided by $\mathrm{R}$. Holcombe and J. Seidman, Harvard University, Boston, MA.

\section{Results}

Categories of TCR $\delta$ gene status. The following categories of TCR $\delta$ genotype were detected: Biallelic germline configuration when the $C \delta$ and the $\mathrm{J} \delta 1$ bands had the expected intensity and no nongermline bands were detectable (G). Because no rigorous densitometry was done, the possibility of germline configuration on one allele and deletion of the complete TCR $\delta$ locus $(C \delta$ and $J \delta 1)$ on the other allele can not always be excluded. The presence of one rearranged $J \delta 1$ band in the presence of a germline $\mathrm{J} \delta 1$ band was scored as R/G (monoallelic rearrangement and germline configuration on the other allele), in the absence of a germline $\mathrm{J} \delta 1$ and decreased intensity of the $C \delta$ band as R/D (i.e., deletion of the $J \delta 1$ and $C \delta$ on one allele), and in the presence of another rearranged $\mathrm{J} \delta 1$ band $(R / R)$. In some cases (i.e., LAZ 221, case 99) we cannot completely rule out the possibility of rearrangements of $3^{\prime}$ joining regions. In the case of missing $\mathrm{C} \delta, \mathrm{J} \delta 1$, and $\mathrm{V} \delta 1$ bands (as detected by $0-240 / 38$ ) this was scored as $\mathrm{D} / \mathrm{D}$, when $\mathrm{V} \delta 1$ was present as D/D, V:G.

Frequency and patterns of TCR $\delta$ recombinatorial events in $T-A L L$ and other leukemias. We first studied the frequency of TCR $\delta$ recombinatorial events in T-ALL and other leukemias in order to evaluate lineage association. Only $9 \%$ of T-ALL were germline for one or both TCR $\delta$ alleles, reflecting a high frequency of recombinatorial events. $61 \%$ had TCR $\delta$ rearrangements and $30 \%$ biallelic deletions. In contrast to the T-ALL, all 15 mature B-lineage malignancies and all 16 ANLL retained the TCR $\delta$ in germline configuration. TCR $\delta$ recombinatorial events were frequently seen in mixed lineage $A L$ ( $80 \%$ ), of which $60 \%$ were rearrangements and $20 \%$ deletions. A very high incidence of $68 \%$ of TCR $\delta$ recombinatorial events was observed in lymphoid precursor ALL; 55\% had rearrangements and $13 \%$ had biallelic deletions. The frequency of TCR $\delta$ recombinatorial events differed between the $\mathrm{CD}^{-} 0^{-}$(cases 70-74) and the CD $10^{+}$lymphoid precursor ALL (cases 75-100) subgroups. Cases 70-74 underwent TCR $\delta$ recombinatorial events in $40 \%(2 / 5)$, compared to $73 \%(19 / 26)$ in the $\mathrm{CD} 0^{+}$subgroup. However, these differences were statistically not significant. Overall, these results indicate a high frequency of TCR $\delta$ recombinatorial events in lymphoid precursor cells.

Further analysis of the pattern of recombinatorial events in T-ALL and lymphoid precursor ALL revealed marked differences between these two groups. The combination of monoallelic rearrangement and germline configuration of the second allele $(R / G)$ prevailed in lymphoid precursor ALL ( $59 \%$ of the rearranged cases). This recombination pattern occurred in only $20 \%$ of the rearranged T-ALL. Biallelic deletions of the TCR $\delta$ locus were observed in 33\% of the T-ALL compared to only $13 \%$ of the lymphoid precursor ALL. Thus deletional events of the TCR $\delta$ locus were by far more frequently seen in T-ALL than in lymphoid precursor ALL. These differences were also reflected in the analysis of individual alleles. In T-ALL, the majority of alleles $(85 \%)$ underwent deletion $(42.5 \%)$ or rearrangement $(42.5 \%)$, whereas in lymphoid precursor ALL the majority of alleles $(47 \%)$ remained in the germline configuration. The usage of the cDNA probe allowed to assess the status of the $V \delta 1$ region in those cases that showed biallelic deletions of the TCR $\delta$ constant and joining regions. Whereas $\mathrm{V} \delta 1$ was not deleted in any of the lymphoid precursor ALL, the majority of T-ALL with deletion of the TCR $\delta$ joining and constant locus (64\%) also deleted the $\mathrm{V} \delta 1$.

$T C R \delta$ rearrangements in various stages of $T$-cell differentiation. We next addressed the question whether frequency and pattern of recombinatorial events in T-ALL were dependent on the stage of differentiation within the $T$-lineage. Three cases retained the TCR $\delta$ gene in the germline configuration, all of which were at the earliest stage of differentiation (early 
Table II. Distinct Types of TCR $\delta$ Rearrangements

\begin{tabular}{ccccc}
\hline & \multicolumn{5}{c}{ Restriction fragment sizes with various enzymes } \\
\cline { 2 - 5 } Type of \\
\cline { 2 - 5 } & Eco RI & Bam HI & Hind III & Xba I \\
\hline & & & $k b$ & \\
1 & 16 & 8 & ND & ND \\
2 & 16 & $16(\mathrm{G})$ & 7.0 & $1.6(\mathrm{G})$ \\
3 & 7.0 & $17.0 / 9.6$ & 7.0 & $1.6(\mathrm{G})$ \\
4 & 6.0 & 17.0 & $5.7(\mathrm{G})$ & 4.2 \\
5 & 4.5 & 15.5 & 9.0 & 9.0 \\
6 & 4.0 & 11.5 & $5.7(\mathrm{G})$ & $1.6(\mathrm{G})$ \\
7 & 4.0 & 6.9 & 5.0 & 10.0 \\
8 & 3.5 & $>23$ & 12 & 9.6 \\
9 & 2.9 & 10.0 & ND & 3.5 \\
10 & $2.0^{*}$ & 9.0 & 5.3 & 9.3 \\
11 & $1.9 *$ & 14.5 & 5.4 & 5.8 \\
12 & 1.0 & 12.0 & 5.7 & 1.8
\end{tabular}

Restriction fragment sizes of TCR $\delta$ rearrangements obtained with different enzymes using $\mathrm{J} \delta \mathrm{S} 16$ as a probe. The sizes of those restriction fragments that comigrate with the respective restriction enzyme germline band are indicated with a (G). The assignment of the restriction fragments of the types 10 and 11 rearrangements were not possible because they occurred in only one leukemia.

thymocyte). In later stages of differentiation, the percentage of biallelic deletions of the TCR $\delta$ locus increased. In the group of mature TCR $\alpha / \beta$ expressing T-lymphocytes all but one (case 28) deleted both TCR $\delta$ alleles. The TCR $\gamma / \delta$ expressing T-ALL rearranged one TCR $\delta$ allele and had the second in a rearranged, deleted or in the germline configuration.

Relationship of TCR $\delta$ and $\gamma$ rearrangements. We next studied whether recombinatorial events of the TCR $\delta$ locus occurred in concordance with TCR $\gamma$ rearrangements. These studies would allow us to determine whether TCR $\delta$ and $\gamma$ genes are rearranged in a hierarchically ordered versus a stochastic pattern. In T-ALL, TCR $\gamma$ gene rearrangements were observed in $91 \%$ of the cases, and no discordant rearrangements between TCR $\gamma$ and TCR $\delta$ were demonstrated. However, discordant rearrangements of the TCR $\delta$ and $\gamma$ genes were observed in $32 \%(10 / 31)$ of the lymphoid precursor ALL. 9 of 10 underwent TCR $\delta$ recombinatorial events $(8$ cases rearrangement of the $J \delta 1$ region, 1 case biallelic deletion of the TCR $\delta$ gene locus) and retained the TCR $\gamma$ gene in the germline configuration, while one lymphoid precursor ALL displayed a monoallelic rearrangement of the TCR $\gamma$ gene with a germline status of the TCR $\delta$ locus. Overall $42 \%$ (13/31) of the lymphoid precursor ALL rearranged the TCR $\gamma$ gene, while $58 \%$ showed a germline pattern. In the group of mixed lineage leukemias and cell lines all cases displayed a concordant status of the TCR $\gamma$ and $\delta$ genes with the exception of RS 4;11 (case 67). RS4;11 retained the TCR $\gamma$ gene in the germline configuration while deleting both TCR $\delta$ alleles. Concordant with the germline configuration of the TCR $\delta$ gene, all 15 mature Blineage malignancies and 16 ANLL retained the TCR $\gamma$ locus in the germline configuration.

Types of rearrangements in $T$-ALL and other leukemias. In order to determine, whether rearrangements detected with the $\mathrm{J} \delta 1$ probe differed in T-ALL and other types of leukemias, 51 rearranged alleles were analyzed with four different restriction enzymes. This approach allowed the identification of a number of distinct rearrangements (Table II; Fig. 2). The sizes of the rearranged bands for Eco RI, Bam HI, Xba I, and Hind III are given in Table II and instructive Southern blots are shown in Figs. 3 and 4.

Evaluation of the distribution of the different rearrangements in various groups of leukemias revealed that types 3 and 6 rearrangements were most frequently found in lymphoid precursor ALL and mixed lineage AL where they accounted for $92 \%$ of the rearrangements (Fig. 2). In T-ALL, the 3.5-kb Eco RI rearrangement (type 8 ) was most frequently seen (seven cases) and accounted for $28 \%$ of the rearranged T-ALL-alleles.

The analysis of TCR $\delta$ rearrangements with the restriction enzymes Xba I and Hind III were particularly instructive. The type 3 rearrangement was not rearranged with $\mathrm{Xba} I$ and the type 6 rearrangement was not rearranged with $\mathrm{Xba} I$ and Hind III. The restriction map of the TCR $\delta$ locus (Fig. 1) locates the $\mathrm{Xba} I$ site between the $\mathrm{J} \delta 1$ and the $\mathrm{D} \delta 2$ regions and the Hind III site $5^{\prime}$ of $\mathrm{D} \delta 2$. Therefore, the type 3 rearrangement most likely represents a joining event of $\mathrm{D} \delta 2$ to a $5^{\prime}$ region, possibly $\mathrm{D} \delta 1$ or a $\mathrm{V} \alpha / \delta$ region. However, recombinations of yet undefined regions $5^{\prime}$ of $J \delta 1$ can not be ruled out. The type 6 rearrangement may represent the recombination of as yet undescribed regions $5^{\prime}$ of $D \delta 2$. The other types of rearrangements described above, were all rearranged with both Hind III and $\mathrm{Xba} \mathrm{I}$, indicating that a $\mathrm{D} \delta 2-\mathrm{J} \delta 1$ join underwent further rearrangement to $5^{\prime}$ regions, possibly $\mathrm{D} \delta 1$ or $\mathrm{V} \alpha / \delta$ region.

Of particular interest is the 3.5-kb Eco RI rearrangement, which was observed in $7 \mathrm{~T}$-ALL and not in other leukemias. This rearrangement has been shown to represent a functional $\mathrm{V} \delta 1-\mathrm{J} \delta 1$ join in leukemic and nonleukemic TCR $\gamma / \delta$ expressing cell lines. Two $\mathrm{CD}^{+} \mathrm{TCR} \gamma^{+}$fresh T-ALL (cases 31 and 32) displayed the identical 3.5 -kb Eco RI rearrangement. In addition, the 3.5-kb Eco $\mathrm{RI}$ rearrangement was observed in the nonleukemic $\mathrm{T} \gamma / \delta$ clone MN-B3, which was $\mathrm{TCS}-1^{+} \mathrm{Ti} \gamma \mathrm{A}^{-}$. The 3.5-kb Eco RI rearrangement was however not restricted to mature $\mathrm{T} \gamma / \delta$ leukemias. Three immature $\mathrm{CD}^{-} \mathrm{Ti}^{-} \mathrm{T}-\mathrm{ALL}$ (cases 5, 21, 22) displayed this rearrangement as well as the expected fragment sizes with the other enzymes.

The type 12 rearrangements cross-hybridized with the $\mathrm{C} \delta$ probe $\mathrm{p} \delta 7$ in Bam HI digests, suggesting the possibility of a V $\delta 3$ rearrangement (see Addendum).

Case 34 was unique in its staining pattern with anti-TCR $\delta$ monoclonal antibodies. The leukemic blasts stained only positive with TCR $\delta 1$, a TCR $\delta$ chain framework antibody (28) and

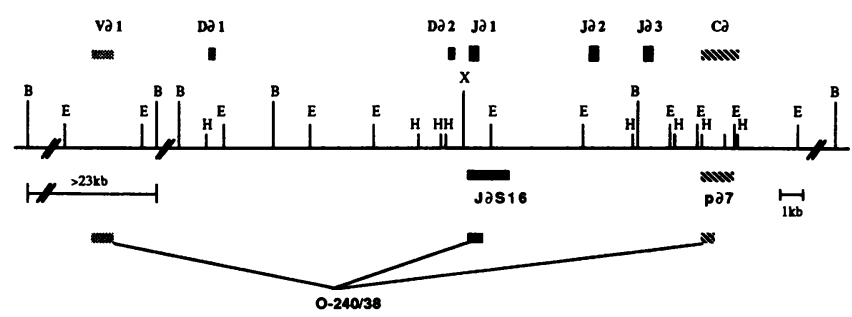

Figure 1. Restriction map of the TCR $\delta$ locus. Bam HI $(B)$, Eco RI $(E)$, Hind III $(H)$, and Xba I $(X)$ sites and the location of the TCR $\delta$ constant $(C \delta)$, joining $(J \delta 1-3)$, and variable $(V \delta 1)$ regions, as well as the diversity elements $(D \delta 1,2)$ are shown. p $\delta 7$ and $J \delta S 16$ are genomic $\mathrm{C} \delta$ and $\mathrm{J} \delta 1$ probes, respectively, $\mathrm{O} / 240-38$ is a $\mathrm{V} \delta 1-\mathrm{J} \delta 1-\mathrm{C} \delta \mathrm{cDNA}$ probe. 


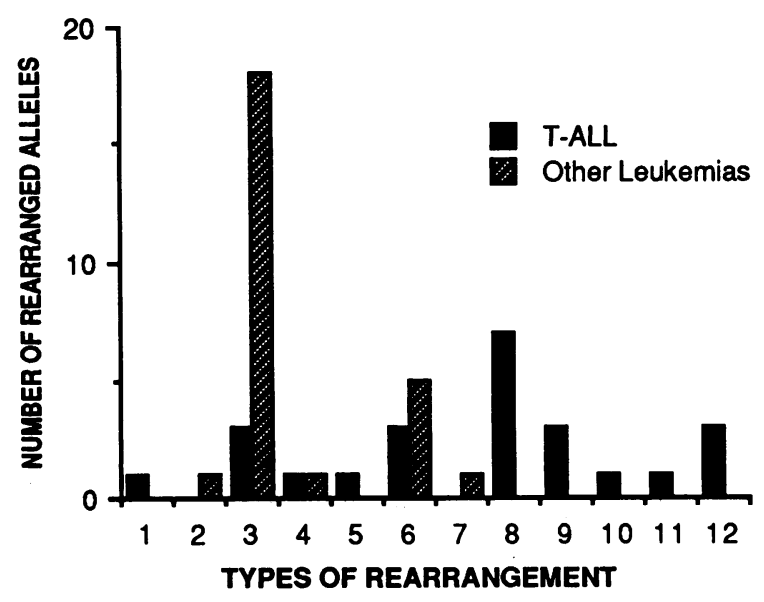

Figure 2. Distribution of distinct TCR $\delta$ rearrangements, as defined in Table II, in T-ALL and other acute leukemias (LP-ALL, mixed lineage $\mathrm{AL}$ ). 51 rearranged alleles were analyzed with Eco RI, Bam $\mathrm{HI}$, Hind III, and Xba I.

$\mathrm{T} \gamma / \delta(29)$. In this leukemia, type 3 and 4 rearrangements were detected, while no 3.5-kb Eco RI rearrangement was observed. In Southern analysis, using the cDNA probe $0-240 / 38$, the $\mathrm{V} \delta 1$ region was not found to be rearranged but remained in the germline configuration. We therefore propose that a so far unidentified $\mathrm{V} \delta$ region was functionally rearranged in this T-ALL. To the knowledge of the authors, this is the first report of a CD3 ${ }^{+} \mathrm{TCR} \gamma / \delta^{+}$leukemia expressing a variable region different from $\mathrm{V} \delta 1$.

\section{Discussion}

$T C R \delta$ recombinatorial events in hematopoitic cells. In this manuscript, we present results on recombinatorial events involving the TCR $\delta$ and $\gamma$ loci in a series of 100 hematological

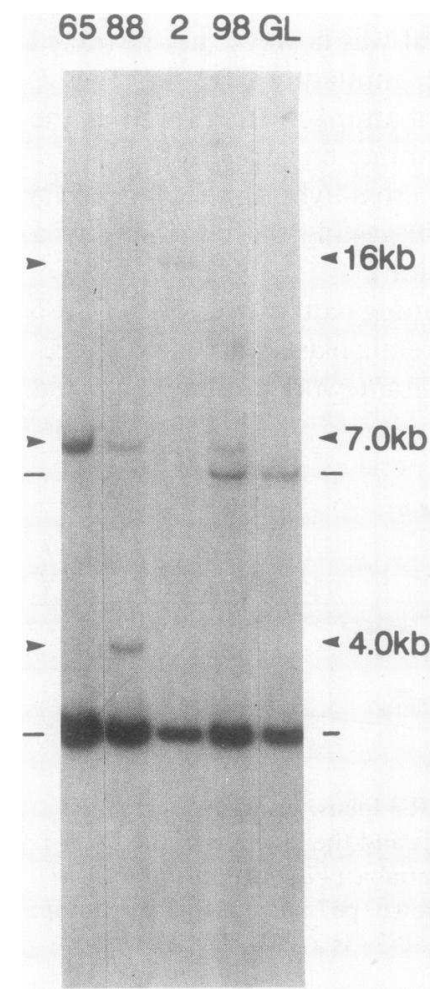

Figure 3. Type 1, 3, and 6 TCR $\delta$ rearrangements in ALL. Demonstration of a monoallelic TCR $\mathrm{J} \delta 1$ rearrangement in case 2 (T-ALL group I). Biallelic TCR $\mathbf{J} \delta 1$ rearrangements (type 3 ) in case 65 , biallelic TCR J $\delta 1$ rearrangements (types 3 and 6) in case 88 (LP-ALL), monoallelic TCR J $\delta 1$ rearrangement (type 3) with germline configuration of the second allele in case 98 (LP-ALL). High molecular DNA was digested with Eco RI and hybridized with $0-240 / 38$. Only the $\mathrm{V} \delta 1$ and $\mathrm{J} \delta 1$ bands are shown. Germline bands are indicated with bars, rearranged bands with arrowheads.

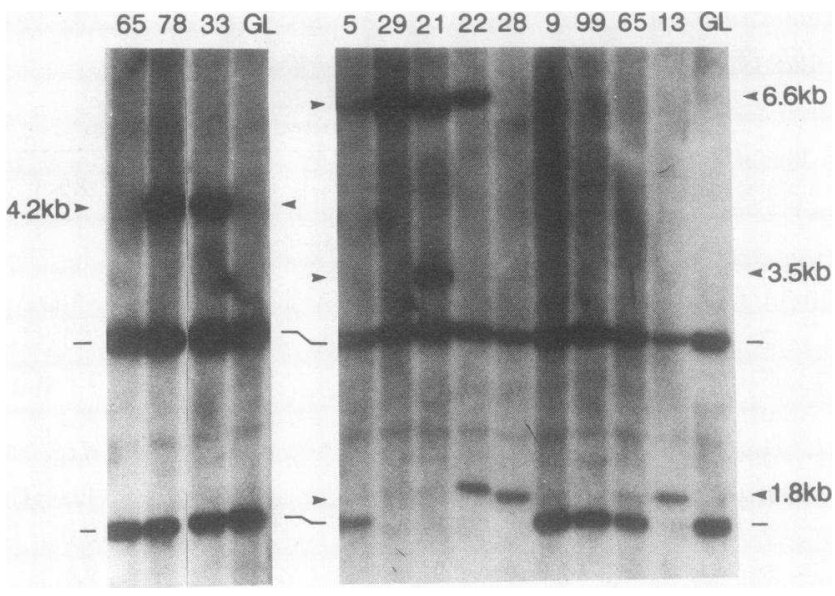

Figure 4. Type 3, 4, 8, 9, 12 TCR $\delta$ rearrangements in ALL. Genomic DNA was digested with Xba I and probed with $\mathrm{J} \delta \mathrm{S} 16$. Types 3 and 4 rearrangements are demonstrated in the cell line KOPN-1 (case 78) and a CD3 ${ }^{+} \mathrm{TCR} \gamma / \delta^{+}$ALL (case 33). Cases 99 (LP-ALL) and 65 (ML-2) which display type 3 rearrangements, and case 9 (TALL group I) which displays a type 6 rearrangement, are not rearranged with Xba I. Type 8 rearrangements in cases 5, 21, 22 and 29, case 21 shows an additional type 9 rearrangement. Cases 13, 22, and 28 display type 12 rearrangements. Rearranged and germline bands are indicated as in Fig. 3.

malignancies. A high incidence of TCR $\delta$ rearrangements and deletions has been reported in T-ALL $(5,17,21,22,41)$, nonleukemic human $(5)$ and mouse $(3,4) \mathrm{T}$-lineage cells. The first aim of the present study was to determine the frequency and lineage association of TCR $\delta$ rearrangements in lymphoid and myeloid precursor leukemias as well as in mature B malignancies and mixed lineage $\mathrm{AL}$. In acute T-lineage leukemias and cell lines, a high percentage of TCR $\delta$ recombinatorial events $(91 \%)$ was found. These results were consistent with the previously reported frequency of TCR $\beta$ and $\gamma$ gene rearrangements in T-ALL and T lineage lymphomas, as well as the recently reported frequency of TCR $\delta$ gene $(21,24,25,41-51)$. We were especially interested in TCR $\delta$ recombinatorial events in lymphoid precursor ALL, i.e., leukemias devoid of definite T-lineage and mature B-lineage differentiation antigens. A high percentage $(68 \%)$ of lymphoid precursor ALL displayed recombinatorial events of the TCR $\delta$ locus, compared to only $45 \%$ rearranging the TCR $\gamma$ gene. The frequency of TCR $\gamma$ rearrangements in lymphoid precursor ALL is similar to the $30-50 \%$ reported previously in this group of leukemia by ourselves and others $(21,22,24,42-45)$. Also similar frequencies of TCR $\delta$ recombinatorial events $(80-90 \%)$ have been recently reported $(21,22)$ in this group of leukemias. Furthermore, the frequency of TCR $\delta$ rearrangements may be underestimated, because rearrangements of not yet described $5^{\prime}$ joining regions, recombinations with the deletional acceptor site " $\delta$ Rec" (20) or $\mathrm{V} \delta$-D $\delta$ rearrangements can not be detected with the probes and the restriction enzymes used in this study (see Fig. 1). In lymphoid precursor ALL the highest incidence of TCR $\delta$ and $\gamma$ rearrangements was observed in leukemias with a $\mathrm{CD} 10^{+} \mathrm{CD} 19^{+}$phenotype. In the present study, $73 \%$ of the $\mathrm{CD} 10^{+} \mathrm{CD} 19^{+}$lymphoid precursor ALL underwent TCR $\delta$ gene recombinatorial events and $48 \%$ rearranged the TCR $\gamma$ gene. In contrast, only $40 \%$ or the $\mathrm{CD}^{-} 0^{-}$lymphoid precursor ALL underwent TCR $\delta$ and 20\% rearranged the TCR $\gamma$ gene. This tendency has been reported previously for the TCR $\gamma$ and 
$\beta$ genes $(38,44,45)$. Unfortunately, our numbers are too small to demonstrate statistically significant differences in the frequency of TCR $\delta$ rearrangements between these two subgroups. Taken these results together, $\mathrm{CD} 10^{+} \mathrm{CD} 19^{+} \mathrm{ALL}$ corearrange IgH and TCR genes with a surprisingly high frequency. These findings raise interesting questions as to which hematopoietic cell is the target cell for malignant transformation in $\mathrm{CD}_{10} \mathrm{CD}^{+} 9^{+} \mathrm{ALL}$. The majority of $\mathrm{CD}^{+} \mathrm{CD}^{+} 9^{+}$ ALL do not express cytoplasmic CD3 or cytoplasmic immunoglobulin and therefore lack markers which indicate commitment to the T- or B-lineage. The other antigens normally expressed on this type of ALL, however, are not lineage- and in some instances not even lymphoid or hematopoietic tissue-restricted. CD10 is expressed on a variety of lymphoid precursor cells, as well as on nonhematopoietic cells such as kidney tubulus and glomerulus cells, neutrophils $(52,53$, reviewed in 54). CD19 is considered to represent a B-lineage associated antigen (52). However, anti-CD19 antibodies have been reported to detect structures on M4 and M5 leukemias (55). Recently, $12 \%$ of 252 de novo ANLL were found to stain positive with the anti-CD19 monoclonal antibody B4 (56). Thus, the CD19 antigen may not be restricted to the B-lineage. In our own series, we identified a $\mathrm{CD} 3^{+} \mathrm{TCR} \gamma / \delta^{+} \mathrm{ALL}$, which coexpressed the CD19 antigen, as demonstrated by dual color staining using three different anti-CD19 monoclonal antibodies. CD24 has been found on B-lineage as well as myeloid cells and HLA-DR is expressed on a wide variety of hematopoietic and nonhematopoietic cells (52).

Taken the phenotypic and genotypic results together, we therefore propose that among the lymphoid precursor leukemias, the $\mathrm{CD} 0^{+} \mathrm{CD} 19^{+}$group is the least likely to be committed to a particular lymphoid lineage. They may be capable of expressing markers of different lineages simultaneously and often co-rearrange $T$ cell receptor and immunoglobulin genes. We cannot however, rule out the possibility that the high frequency of rearrangements of both TCR and IgH genes may be due to posttransformational events (57), i.e., are inherent to the malignant state of leukemias. According to this hypothesis, the leukemic cells would continue to rearrange genes of the immunoglobulin supergene family as they are arrested in a stage of lymphoid development with an active recombinase and open chromatin structure at TCR and IgH loci. This hypothesis would predict the frequent occurrence of polyclonal or in case that certain rearrangements conferred growth advantage, oligoclonal rearrangements in lymphoid precursor leukemias. However, in none of the 64 immature leukemias did we observe oligo- or polyclonal rearrangements of the TCR genes. We therefore favor the hypothesis of a not yet committed lymphoid precursor cell as the target cell in $\mathrm{CD} 10^{+} \mathrm{CD} 19^{+}$ acute lymphoblastic leukemia. It will be important to identify the normal, nonleukemic counterparts of these leukemias.

The pattern of recombinatorial events was different in T-ALL and lymphoid precursor ALL. Lymphoid precursor ALL tended to undergo recombinatorial events only on one allele, while in T-ALL biallelic recombinatorial events prevailed. These data are similar to the TCR $\gamma$ gene, where lymphoid precursor ALL predominantly display monoallelic and T-ALL biallelic rearrangements $(24,43-46,51)$. Similarly to the lymphoid precursor ALL, TCR $\delta$ recombinatorial events were frequently observed in mixed lineage $\mathrm{AL}$. In contrast to the lymphoid precursor ALL, none of the mature B-lineage cell lines and malignancies rearranged the TCR $\delta$ locus. These findings are consistent with previous reports on the low inci- dence of rearrangements of the TCR $\gamma$ and $\beta$ genes in mature B-lineage cells $(58,59)$. Our findings confirm the hypothesis that in the cases of mature B-cell lymphoma and B-CLL, a more mature and committed cell undergoes malignant transformation.

The analysis of the myeloid leukemias and cell lines revealed that all 16 cases studied retained the TCR $\delta$ gene in the germline configuration. These findings are consistent with the previous results obtained by ourselves (24) and others (60) in acute nonlymphoblastic leukemias in which no TCR $\gamma$ and $\beta$ or IgH rearrangements were present. These observations confirm the notion that only rare myeloid leukemias will undergo rearrangement of members of the immunoglobulin supergene family. However, a larger sample number may reveal a low percentage of TCR $\delta$ rearrangements and deletions as has been shown for TCR $\gamma$ and $\beta$ and the immunoglobulin heavy chain genes $(61,62)$. In conclusion, these data suggest $(a)$ a certain restriction of TCR $\delta$ rearrangements to lymphoid precursor cells and $(b)$ that rearrangements of the TCR $\delta$ gene are useful clonal markers, but are not restricted to cells committed to the T-lineage. Many cases of lymphoid precursor ALL appear to be not yet definitely committed to a particular lineage, but rearrange either TCR or immunoglobulin genes or both.

Hierarchy of TCR $\delta$ and $\gamma$ rearrangements. We next analyzed the frequency and pattern of TCR $\delta$ rearrangements at different stages of differentiation within the T-lineage. Of 33 T-lineage ALL and T-cell lines studied, only immature T-ALL expressing a phenotype of early thymocytes (31) retained the TCR $\delta$ gene in the germline configuration. Although the TCR $\delta$ gene is rearranged and transcribed very early in T-lineage ontogeny, these data may suggest that the commitment of a lymphoid precursor cell to the T-lineage may not require TCR $\delta$ rearrangements. A lower incidence of rearrangements of the TCR $\gamma$ and $\beta$ genes $(24,63,64)$ has been previously reported in these early cells of the T-lineage. Recent studies in murine T-precursor clones showed that the TCR $\gamma$ and $\beta$ genes remained in the germline configuration (65).

We and others have proposed that similarly to the immunoglobulin heavy and light chain genes, rearrangements of the TCR genes may observe a developmental hierarchy during thymic development, that is TCR $\gamma$ and $\beta$ rearrange before TCR $\alpha(24,48,63,64)$. Although it has been demonstrated that TCR $\gamma$ and $\delta$ are transcribed early in T cell ontogeny (3), the precise order of rearrangements is unknown. In our series of 33 T-ALL, no discordant TCR $\delta$ and $\gamma$ rearrangements were observed. These results are consistent with previous reports that TCR $\gamma$ and $\delta$ genes are generally rearranged concordantly in T-ALL $(17,21)$. In contrast to T-ALL, discordant rearrangements between TCR $\delta$ and $\gamma$ were frequently observed in lymphoid precursor ALL, the majority of which had undergone recombinations involving the TCR $\delta$ gene while retaining the TCR $\gamma$ gene in the germline configuration. Similar results were reported recently $(21,22)$. Based on these findings we propose that the TCR $\delta$ gene may be rearranged before the TCR $\gamma$ gene very early in lymphoid development. T-ALL may originate from more mature cells that have already undergone both TCR $\delta$ and $\gamma$ rearrangements. Further studies in nonleukemic precursor cells are necessary to evaluate the question, whether lymphoid precursor leukemias can be used as a paradigm of lymphoid differentiation.

The frequency of TCR $\delta$ deletions was highest in more mature stages of $\mathrm{T}$ cell differentiation. Whereas deletions were seen in $25 \%$ of the alleles in early thymocytes and in $55 \%$ of the 
common thymocytes, all but one TCR $\alpha / \beta^{+}$leukemias displayed biallelic deletion of the TCR $\delta$ locus. This and two previous instances (17) are consistent with the idea that a functional rearrangement of the TCR $\alpha$ gene may be achieved without deleting noth TCR $\delta$ alleles. Of interest is the fact that many of the cases of leukemias with biallelic deletion of the TCR $\delta$ constant and joining regions retained the major $\mathrm{V} \delta$ regions (V $\delta 1)$ in the germline configuration. Thus, the TCR $\delta$ deletional mechanism may be activated without prior attempt to rearrange the major variable region $\mathrm{V} \delta 1(3,4,20,40)$.

Types of TCR $\delta$ rearrangements in leukemias. Determination of the diversity of TCR $\delta$ gene would provide useful insight in the overall diversity of the TCR $\gamma / \delta$ heterodimers and possibly lead to a better understanding of the function of this T-cell receptor. In this study we sought to determine whether one of the $J \delta$ regions was used preferentially. Of 200 evaluable alleles, all either retained $J \delta 1$ in the germline configuration or rearranged $J \delta 1$ or deleted the complete TCR $\delta$ locus (constant and joining regions). In six alleles, it was not possible to rule out the rearrangement of a joining region $3^{\prime}$ of $\mathrm{J} \delta 1$ (J $\left.\delta 2\right)$. Similar results were obtained in studies in mouse and human (4, $21,66,67$ ), suggesting that the $3^{\prime}$ joining regions $J \delta 2$ and 3 are used infrequently.

Analysis of 51 rearranged alleles with four different restriction enzymes allowed the identification of distinct types of rearrangements. These seem to be nonrandomly used in different types of leukemias. Preferential usage of TCR $\gamma$ joining and variable $(11,12,14)$ and of TCR $\alpha$ joining regions (17) between T- and non-T-ALL have been reported previously. In addition, it was possible to evaluate the hypothesis whether lymphoid precursor ALL represent the least mature cell types and therefore are likely to demonstrate the earliest stages of TCR $\delta$ rearrangements. Specifically, it has been proposed by murine thymocyte studies that V-D $\delta$ or $\mathrm{D} \delta$-D $\delta$ rearrangements may represent the earliest recombinatorial events of the TCR $\delta$ locus $(4,15)$. Rearrangements that do not delete intervening sequences between $\mathrm{J} \delta 1$ and $\mathrm{D} \delta 2$ have been recently reported to prevail in non-T-ALL (21). The type 3 TCR $\delta$ rearrangement (Table II) is consistent with a $\mathrm{D} \delta$-D $\delta 2$ or $\mathrm{V} \alpha / \delta$-D $\delta 2$ rearrangement. The second most frequent rearrangement in lymphoid precursor ALL (type 6) is consistent with a joining event not involving $\mathrm{J} \delta 1$, but most likely rearranging regions $5^{\prime}$ of $\mathrm{D} \delta 2$. The existence of rearranging regions in addition to the known diversity elements $D \delta 1$ has also been proposed in the murine TCR $\delta$ locus (15). The types 3 and 6 rearrangements accounted for $84 \%$ of the rearrangements in lymphoid precursor ALL and $100 \%$ in mixed lineage AL.

Leukemias of the $\mathrm{T}$-lineage are more mature than those involving lymphoid precursors and therefore are more likely to demonstrate more mature and complex rearrangements. In fact, T-ALL differed from lymphoid precursor ALL by the presence of rearrangements representing joining events of $J \delta 1$ to upstream regions. $28 \%$ of the T-ALL alleles had $\mathrm{J} \delta 1$ rearrangements compared to $5 \%$ of the lymphoid precursor ALL alleles.

The limited number of TCR $\delta$ rearrangements in the present study was remarkable. These data suggest a limited genomic repertoire of the TCR $\delta$ gene, as previously proposed for the murine TCR $\delta$ gene $(4,10,67,69)$. Analysis of functional TCR $\gamma$ genes reveals that the functional diversity may be limited to only three variable regions $\left(\mathrm{V}_{\gamma} 5, \mathrm{~V}_{\gamma} 8\right.$, and $\left.\mathrm{V}_{\gamma} 9\right)(14$, $30,68)$. In TCR $\delta$ limited usage of $V \delta$ regions has been demonstrated in mouse thymocytes and T-lymphocytes and in a number of $\mathrm{T} \gamma / \delta$ cell lines $(3,4,5,7,10,66-69)$. We therefore sought to determine whether additional functional TCR $\delta$ rearrangements exist in humans.

One leukemia, which expresses the $\mathrm{T} \gamma / \delta$ receptor (case 33 ) is of special interest. This leukemia presumably uses a different $\mathrm{V} \delta$ region than cases $29-32$ and those of others $(5-7,66,67)$. The negative staining pattern with $\delta$ TCS- 1 which is considered to detect a variable structure of the $\mathrm{V} \delta 1-\mathrm{J} \delta 1$ TCR $\delta$ gene product (28) adds more evidence to the hypothesis that this leukemia expresses a TCR $\delta$ gene product which is different from the $\mathrm{V} \delta 1-\mathrm{J} \delta 1$ gene product, typically seen in the PEER cell line (type 8 rearrangement) (see Addendum). In conclusion, our data suggest that only a small number of $\mathrm{V} \delta$ regions, at least two, are available for functional rearrangements.

\section{Addendum}

During the time of the review of this manuscript, two new $\mathrm{V} \delta$ regions were described by Hata et al. J. Exp. Med. 169:41-57, 1989. In Xba I digests, $\mathrm{V} \delta 2$ and $\mathrm{V} \delta 3$ joining events to $\mathrm{J} \delta 1$ yielded rearranged bands of $4.2 \mathrm{~kb}$ and $1.9 \mathrm{~kb}$, respectively. These sizes are virtually identical to the $\mathrm{Xba}$ I sizes of the type $4(4.2 \mathrm{~kb})$ and type $12(1.8 \mathrm{~kb})$ rearrangements suggesting that the type 4 rearrangement is a $V \delta 2-(\mathrm{D})-\mathrm{J} \delta 1$ and the type 12 rearrangement a $\mathrm{V} \delta 3$-(D)-J $\delta 1$ rearrangement. Studies are under way to confirm this hypothesis.

\section{Acknowledgments}

The authors thank Christopher W. Wilkowski for expert technical assistance preparing probes and Lia Gore and Celia Connoy for editorial assistance.

This work was supported in part by the following grants from the National Institutes of Health: CA-25097 and CA-21737 and the University of Minnesota Children's Cancer Research Fund and Leukemia Research Fund. Frank Griesinger is recipient of a fellowship from the Deutsche Forschungsgemeinschaft (Gr 301/1-1). James M. Greenberg is a Special Fellow of the Leukemia Society of America.

\section{References}

1. Greaves, M. F., L. C. Chan, A. J. W. Furley, S. M. Watt, and H. V. Molgaard. 1986. Lineage promiscuity in hematopoietic differentiation and leukemia. Blood. 67:1-11.

2. Korsmeyer, S. J. 1987. Antigen receptor genes as molecular markers of lymphoid neoplasms. J. Clin. Invest. 79:1291-1295.

3. Chien, Y., M. Iwashima, K. B. Kaplan, J. F. Elliott, and M. M. Davis. 1987. A new T-cell receptor gene located within the alpha locus and expressed early in T-cell differentiation. Nature (Lond.). 327:677682.

4. Chien, Y., M. Iwashima, D. A. Wettstein, K. B. Kaplan, J. F. Elliott, W. Born, and M. M. Davis. 1987. T-cell receptor $\delta$ rearrangements in early thymocytes. Nature (Lond.). 330:722-727.

5. Hata, S., M. B. Brenner, and M. S. Krangel. 1987. Identification of putative human T-cell receptor $\delta$ complementary DNA clone. Science (Wash. DC). 238:678-862.

6. Band, H., F. Hochstenbahc, J. McLean, M. S. Krangel, and M. B. Brenner. 1987. Immunochemical proof that a novel rearranging gene encodes the T cell receptor $\delta$ subunit. Science (Wash. DC). 238:682-684.

7. Loh, E. Y., L. L. Lanier, C. W. Turck, R. Littman, M. M. Davis, Y.-h. Chien, and A. Weiss. 1987. Identification and sequence of a fourth human $T$ cell antigen receptor chain. Nature (Lond.). 330:569572.

8. Snowder, J. T., C.-L. H. Chen, L. L. Ager, M. M. Chan, and M. D. Cooper. 1988. A large subpopulation of avian T-cells express a homologue of the mammalian T $\gamma / \delta$ receptor. J. Exp. Med. 167:315322. 
9. Goodman, T., and L. Lefrançois. 1988. Expression of the $\gamma-\delta$ T-cell receptor on intestinal $\mathrm{CD}^{+}{ }^{+}$intraepithelial lymphocytes. Nature (Lond.). 333:855-858.

10. Davis, M. M., and P. J. Bjorkman. 1988. T-cell antigen receptor and T-cell recognition. Nature (Lond.). 334:395-402.

11. Chen, Z., M. P. Font, P. Loiseau, J. C. Bories, L. Degos, M. P. Lefranc, and F. Sigaux. 1988. The human T-cell $V_{\gamma}$ gene locus: cloning of new segments and study of $\mathrm{V} \gamma$ rearrangements in neoplastic $\mathrm{T}$ and B cells. Blood. 72:776-783.

12. Huck, S., and M.-P. Lefranc. 1987. Rearrangements to the JP1, JP and JP2 segments in the human T-cell rearranging gamma gene (TRG $\gamma$ ) locus. FEBS (Fed. Eur. Biochem. Soc.) Lett. 224:291-296.

13. Forster, A., S. Huck, N. Ghanem, M. P. Lefranc, and T. H. Rabbitts. 1987. New subgroups in the human $\mathrm{T}$ cell rearranging $\mathrm{V}_{\boldsymbol{\gamma}}$ locus. EMBO (Eur. Mol. Biol. Organ.) J. 6:1945-1950.

14. Gonzalez-Sarmiento, R., J. M. Greenberg, and J. H. Kersey. 1988. Usage of gamma chain variable regions in human acute lymphoblastic leukemias. Blood. 72:2038-2041.

15. Okazaki K., and H. Sakano. 1988. Thymocyte circular DNA excised from T cell receptor $\alpha-\delta$ gene complex. EMBO (Eur. Mol. Biol. Organ.) J. 7:1669-1674.

16. Boehm, T., R. Baer, I. Lavenir, A. Forster, J. J. Waters, E. Nacheva, and T. H. Rabbitts. 1988. The mechanism of chromosomal translocation $\mathrm{t}(11 ; 14)$ involving the T-cell receptor $\mathrm{C} \delta$ locus on human chromosome $14 \mathrm{q} 11$ and a transcribed region of chromosome $11 \mathrm{p} 15$. EMBO (Eur. Mol. Biol. Organ.) J. 7:385-394.

17. Baer, R., T. Boehm, H. Yssel, and T. H. Rabbitts. 1988. Complex rearrangements within the human $\mathrm{J} \delta-\mathrm{C} \delta / \mathrm{J} \alpha-\mathrm{C} \alpha$ locus and aberrant recombination between $\mathrm{J} \alpha$ segments. EMBO (Eur. Mol. Biol. Organ.) J. 7:1661-1668.

18. Boehm, T., L. Buluwela, D. Williams, L. White, and T. H. Rabbitts. 1988. A cluster of chromosome $11 \mathrm{p} 13$ translocation found via distinct $D-D$ and $D-D-J$ rearrangements of the human $T$ cell receptor $\delta$ chain gene. EMBO (Eur. Mol. Biol. Organ.) J. 7:2011-2017.

19. de Villartay, J.-P., D. Lewis, R. Hockett, T. A. Waldmann, S. J. Korsmeyer, and D. I. Cohen. 1987. Deletional rearrangement in the human T-cell receptor $\alpha$ chain locus. Proc. Natl. Acad. Sci. USA. 84:8608-8612.

20. de Villartay, J.-P., R. Hockett, D. Coran, S. J. Korsmeyer, and D. I. Cohen. 1988. Deletion of the human T-cell receptor $\delta$ gene by a site specific recombination. Nature (Lond.). 335:170-174.

21. Hara, J., S. H. Benedict, E. Champagne, Y. Takihara, T. W. Mak, M. Minden, and E. W. Gelfand. 1988. T cell receptor $\delta$ gene rearrangements in acute lymphoblastic leukemia. J. Clin. Invest. 82:1974-1982.

22. Felix, C. A., D. G. Poplack, G. H. Reaman, D. E. Cole, C. G. Begley, A. Gillespie, and I. T. Kirsch. 1988. Characterization and classification of B-cell precursor acute lymphoblastic leukemia (ALL) of childhood by immunoglobulin (Ig) and T-cell receptor (TCR) gene patterns. Blood. 72(Suppl. 1):198a.

23. Griesinger, F., D. C. Arthur, R. Brunning, J. L. Parkin, A. C. Ochoa, W. J. Miller, C. W. Wilkowski, J. M. Greenberg, C. Hurvitz, and J. H. Kersey. 1989. Mature T-lineage leukemia with growth factor induced multilineage differentiation. J. Exp. Med. 169:1101-1120.

24. Greenberg, J. M., T. Quertermous, J. G. Seidman, and J. H. Kersey. 1986. Human $T$ cell $\gamma$ chain gene rearrangements in acute lymphoid and nonlymphoid leukemia. Comparison with the $\mathrm{T}$ cell receptor $\beta$ chain gene. J. Immunol. 137:2043-2049.

25. Greenberg, J. M., and J. H. Kersey. 1987. Terminal deoxynucleotidyl transferase expression can precede T cell receptor $\beta$ and $\gamma$ chain rearrangement in $\mathrm{T}$ cell acute lymphoblastic leukemia. Blood. 69:356-360.

26. Stong, R. C., S. J. Korsmeyer, J. L. Parkin, D. C. Arthur, and J. H. Kersey. 1985. Human acute leukemic cell line with the $t(4 ; 11)$ chromosomal rearrangement exhibits B-lineage and monocytic characteristics. Blood. 65:21-31.

27. Kurtzberg, J., S. H. Bigner, and M. S. Hershfield. 1985. Establishment of the DU.528 human lymphohematopoietic stem cell line. $J$. Exp. Med. 162:1561-1578.
28. Faure, F., S. Jitsukawa, F. Triebel, and T. Hercend. 1988. Characterization of human peripheral lymphocytes expressing the CD $3 / \gamma / \delta$ complex with anti-receptor monoclonal antibodies. $J$. Immunol. 141:3357-3360.

29. Borst, J., J. J. M. van Dongen, R. L. Bolhuis, P. J. Peters, D. A. Hafler, E. de Vries, and R. J. van de Griend. 1988. Distinct molecular forms of human $T$ cell receptor $\gamma / \delta$ detected on viable $T$ cells by a monoclonal antibody. J. Exp. Med. 167:1625-1644.

30. Jitsukawa, S., R. Faure, M. Lipinski, F. Triebel, and T. Hercend. 1987. A novel subset of human lymphocytes with T-cell receptor $\gamma$ complex. J. Exp. Med. 166:1192-1197.

31. Reinherz, E. L., P. C. Kung, G. Goldstein, R. H. Levey, and S. L. Schlossman. 1980. Discrete stages of human intrathymic differentiation: Analysis of normal thymocytes and leukemic lymphoblasts of T-cell lineage. Proc. Natl. Acad. Sci. USA. 77:1588-1592.

32. Littman, D. R., M. Newton, D. Cormmie, S.-L. Ang, J. G. Seidman, S. N. Gettner, and A. Weiss. 1987. Characterization of an expressed $\mathrm{CD} 3$-associated $\mathrm{Ti} \gamma$ chain reveals $\mathrm{C} \gamma$ polymorphism. $\mathrm{Na}$ ture (Lond.). 326:85-88.

33. Spits, H., J. Borst, W. Tax, P. J. A. Capel, C. Terhorst, and J. E. de Vries. 1985. Characteristics of a monoclonal antibody (WT31) that recognizes a common epitope on the human $\mathrm{T}$ cell receptor for antigen. J. Immunol. 135:1922-1928.

34. van de Griend, R. J., J. Borst, W. J. M. Tax, R. L. H. Bolhuis. 1988. Functional reactivity of WT31 monoclonal antibody with T cell receptor $\gamma$ expressing $\mathrm{CD}^{+} 4^{-} 8^{-} \mathrm{T}$ cells. J. Immunol. 140:1107-1110.

35. Bennett, J. M., D. Catovski, M. T. Daniel, G. Flandrin, D. A. G. Galton, H. R. Gralnick, and C. Sultan. 1985. Proposed revised criteria for the classification of acute myeloid leukemia. A report of the French-American-British cooperative group. Ann. Intern. Med. 103:620-625.

36. Furley, A. J., B. R. Reeves, S. Mitzutani, L. J. Altass, S. M. Watt, M. C. Jacob, P. van den Elsen, C. Terhorst, and M. F. Greaves. 1986. Divergent molecular phenotypes of KG-1 and KG1a myeloid cell lines. Blood. 68:1101-1107.

37. Look, A. T., S. C. Peiper, and R. A. Ashmun. 1987. Binding of independently derived monoclonal antibodies to unique human myeloid differentiation antigens. In Leukocyte Typing III, White Cell Differentiation Antigens. A. J. McMichael, editor. Oxford University Press, Oxford. 3rd ed. 626-629.

38. Feinberg, A. P., and B. Vogelstein. 1983. A technique for radiolabeling DNA restriction endonuclease fragments to high specific activity. Anal. Biochem. 132:6-13.

39. Satyanarayana, K., S. Hatam, P. Devlin, M. G. Roncarolo, J. E. de Vries, H. Spits, J. L. Strominger, and M. S. Krangel. 1988. Genomic organization of the human T-cell antigen-receptor $\alpha / \delta$ locus. Proc. Natl. Acad. Sci. USA. 85:8166-8170.

40. Dialynas, D. P., C. Murre, T. Quertermous, J. M. Boss, J. M. Leiden, J. G. Seidman, and J. L. Strominger. 1986. Cloning and sequence analysis of complementary DNA encoding an aberrantly rearranged human T-cell $\gamma$ chain. Proc. Natl. Acad. Sci. USA. 83:26192523.

41. Tkachuk, D. C., H. Griesser, Y. Takihara, E. Champagne, M. Minden, A. C. Feller, K. Lennert, and T. W. Mak. 1988. Rearrangement of $\mathrm{T}$ cell $\delta$ locus in lymphoproliferative disorders. Blood. 72:352-357.

42. Asou, N., M. Matsuoka, T. Hattori, F. Kawano, S. Maeda, K. Shimada, and K. Takatsuki. 1987. T cell $\gamma$ rearrangements in hematologic neoplasms. Blood. 69:968-970.

43. Felix, C. A., G. H. Reaman, S. J. Korsmeyer, G. F. Hollis, P. A. Dinndorf, J. J. Wright, and I. R. Kirsch. 1987. Immunoglobulin and T-cell receptor gene configuration in acute lymphoblastic leukemia of infancy. Blood. 70:536-541.

44. Le Paslier, D., Z. Chen, P. Loiseau, D. Cohen, and F. Sigaux. 1987. $T$ cell rearranging gene $\gamma$ : diversity and mRNA expression in fresh cells from $T$ cell acute lymphoblastic leukemia. Blood. 70:637646.

45. Goorha, R., N. Bunin, J. Mirro Jr., S. B. Murphy, A. H. Cross, F. G. Behm, T. Quertermous, J. Seidman, and G. R. Kitchingman. 
1987. Provocative pattern of rearrangements of the genes for the $\gamma$ and $\beta$ chains of the T-cell receptor in human leukemias. Proc. Natl. Acad. Sci. USA. 84:4547-4551.

46. Hara, J., S. H. Benedict, T. W. Mak, and E. W. Gelfand. 1987. $\mathrm{T}$ cell receptor $\alpha$-chain gene rearrangements in B-precursor leukemia are in contrast to the findings in $\mathrm{T}$ cell acute lymphoblastic leukemia. J. Clin. Invest. 80:1770-1777.

47. Hara, J., S. H. Benedict, E. Champagne, T. W. Mak, M. Minden, and E. W. Gelfand. 1988. Comparison of T cell receptor $\alpha, \beta$, and $\gamma$ gene rearrangement and expression in $T$ cell acute lymphoblastic leukemia. J. Clin. Invest. 81:989-996.

48. Foroni, L. E., E. Matutes, J. Foldi, R. Morilla, T. H. Rabbitts, L. Luzzato, and D. Catovski. 1988. T-cell leukemias with rearrangement of the $\gamma$ but not the $\beta$ T cell receptor genes. Blood. 71:356-362.

49. Felix, C. A., J. J. Wright, D. G. Poplack, G. H. Reaman, D. Cole, P. Goldman, and S. J. Korsmeyer. 1987. T-cell receptor $\alpha$-, $\beta$ and $\gamma$-genes in T cell and pre-B cell acute lymphoblastic leukemia. $J$. Clin. Invest. 80:545-556.

50. Griesser, H., A. Feller, K. Lennert, M. Minden, and T. W. Mak. 1986. Rearrangement of the $\beta$ chain of the $T$ cell antigen receptor and immunoglobulin genes in lymphoproliferative disorders. J. Clin. Invest. 78:1179-1184.

51. Minden, M. D., and T. W. Mak. 1986. The structure of the T cell antigen receptor genes in normal and malignant $\mathrm{T}$ cells. Blood. 68:327-336.

52. Ling, N. R., I. C. M. MacLennan, and D. Y. Mason. 1987. B-cell and plasma cell antigens: new and previously defined clusters. In Leukocyte Typing III, White Cell Differentiation Antigens. A. J. McMichael, editor. Oxford University Press: 321.

53. McCormack, R. T., R. D. Nelson, and T. W. LeBien. 1986. Structure/function studies of the common acute lymphoblastic leukemia antigen (CALLA/CD10) expressed on human neutrophils. J. Immunol. 137:1075-1082.

54. LeBien, T. W., and R. T. Mc Cormack. 1989. The common acute lymphoblastic leukemia antigen (CD10)-Emancipation from a functional enigma. Blood. 73:625-635.

55. Campos, L., D. Guyotat, O. Gentilhomme, D. Treille, D. Fiere, and D. Germain. 1987. Expression of a B-lymphoid differentiation antigen (CD19) on acute non-lymphoblastic leukaemia cells. In Leukocyte Typing III, White Cell Differentiation Antigens. A. J. McMichael, editor. Oxford University Press, Oxford. 3rd ed. 470-473.

56. Ball, E. D., J. D. Griffin, R. Davis, F. R. Davey, D. Arthur, D. Wurster-Hill, S. Schiffer, and C. Bloomfield. 1988. Prognostic value of lymphocyte surface markers in acute myeloid leukemia (AML): a cancer and leukemia group B (CALGB) study. Blood. 72(Suppl. 1):187a. (Abstr.)

57. Smith, L. J., J. E. Curtis, H. A. Messner, J. S. Senn, H. Futhmayr, and E. A. Culloch. 1983. Lineage infidelity in acute leukemia. Blood. 61:1138-1145.
58. Norton, J. D., J. Patterson, A. V. Hoffbrand, H. Jani, J. C. Yaxley, and B. F. Leber. 1988. Rearrangement and expression of T cell antigen receptor genes in B cell chronic lymphocytic leukemia. Blood. 71:178-185.

59. Aisenberg, A. C., B. M. Wilkes, J. O. Jacobson. 1987. Rearrangement of the genes for the beta and gamma chain genes of the $T$ cell receptor is rarely observed in adult $B$ cell lymphoma and chronic lymphocytic leukemia. J. Clin. Invest. 80:1209-1214.

60. Ackland, S. P., C. A. Westbrook, M. O. Diaz, M. M. LeBeau, and J. D. Rowley. 1987. Evidence favoring lineage fidelity in acute nonlymphoblastic leukemia: absence of immunoglobulin gene rearrangements in FAB types M4 and M5. Blood. 69:87-91.

61. Cheng, G. Y., M. D. Minden, B. Toyonaga, T. W. Mak, and E. A. Culloch. 1986. T cell receptor and immunoglobulin gene rearrangements in acute myeloblastic leukemia. J. Exp. Med. 163:414424.

62. Foa, R., G. Casorati, M. C. Giubellino, G. Basso, R. Schirro, G. Pizzolo, F. Lauria, M.-P. Lefranc, T. H. Rabbitts, and N. Migone. 1987. Rearrangements of immunoglobulin and T cell receptor $\beta$ and $\gamma$ genes are associated with terminal deoxynucleotidyl transferase expression in acute myeloid leukemia. J. Exp. Med. 165:879-890.

63. Sangster, R. N., J. Minowada, N. Suciu-Foca, M. D. Minden, and T. W. Mak. 1987. Rearrangement and expression of the $\alpha, \beta$, and $\gamma$ chain $T$ cell receptor genes in human thymic leukemia cells and functional T cells. J. Exp. Med. 163:1491-1508.

64. Davey, M. P., K. F. Bongiovanni, W. Kaulfersch, M. M. Davis, and T. A. Waldman. 1986. Immunoglobulin and T-cell receptor gene rearrangement and expression in human lymphoid leukemia cells at different stages of maturation. Proc. Natl. Acad. Sci. USA. 83:87598763.

65. Palacios, R., M. Kiefer, M. Brockhaus, K. Karjalainene, S. Dembic, P. Kisielow, and H. von Boehmer. 1987. Molecular, cellular and functional properties of bone marrow $\mathrm{T}$ lymphocyte progenitor clones. J. Exp. Med. 166:12-32.

66. Hata, S., K. Satyanarayana, P. Devlin, H. Band, J. McLean, J. L. Strominger, M. B. Brenner, and M. S. Krangel. 1988. Extensive junctional diversity of rearranged human $\mathrm{T}$ cell receptor $\delta$ genes. Science (Wash. DC). 240:1541-1544.

67. Elliott, J. R., E. P. Rock, M. M. Davis, and Y.-h. Chien. 1988. The adult T-cell receptor $\delta$ chain is diverse and distinct from that of fetal thymocytes. Nature (Lond.). 331:627-631.

68. Triebel, F., F. Faure, M. Graziani, S. Jitsukawa, M.-P. Lefranc, and T. Hercend. 1988. A unique V-J-C rearranged gene encodes a $\gamma$ protein expressed on the majority of $\mathrm{CD}^{+} \mathrm{T}$ cell receptor- $\alpha / \beta^{-}$circulating lymphocytes. J. Exp. Med. 167:694-699.

69. Korman, A. J., S. Marusic-Galesic, D. Spencer, A. M. Kruisenbeek, and D. H. Raulet. 1988. Predominant variable region gene usage by $\gamma / \delta \mathrm{T}$ cell receptor-bearing cells in the adult thymus. J. Exp. Med. 168:1021-1040. 